Rev. Hist., N²5, vol. 1, enero-junio 2018: $131-159$

ISSN 0717-8832

\title{
Historia y cultura de la nación indígena Mbayá-Guaycurúe: elementos de su trayectoria en la frontera colonial hispano-portuguesa del siglo XVIII
}

History and culture of the Mbayá-Guaycurúe indigenous nation: elements of its trajectory in the Spanish-Portuguese colonial border of the 18th century.

\section{RESUMEN}

Ney Alves de Arruda

Los objetivos están centrados en: desarrollar la sensibilización cultural a partir de la historia de los naturales, conocer aspectos del vivir nativo en el siglo determinado, entender la importancia de los Mbayá-Guaycurúes en el contexto de la raya histórica. Las fuentes son publicaciones del acervo de la Biblioteca de Estudios Hispano-Americanos y de la Biblioteca del Archivo General de Indias en Sevilla, de igual forma, de la Biblioteca del Archivo Público del Estado del Mato Grosso (Brasil). Las resultantes quedan en una visión histórica mucho más puntualizada desde una perspectiva histórico-antropológica acerca de la etnia nativa conforme las conclusiones.

Palabras Clave: bordas históricas, indígenas, Mbayá-Guaycurúe, siglo XVIII.

\section{ABSTRACT}

The objectives are focused on: developing cultural awareness based on the history of the natives, knowing aspects of native life in the given century, understanding the importance of the MbayáGuaycurúes in the context of the historical line. The sources are publications of the collection of the Library of Hispanic-American Studies and of the Library of the General Archive of the Indies in Seville, likewise, of the Library of the Public Archive of the State of Mato Grosso (Brazil). The results remain in a historical vision much more specific from a historical-anthropological perspective about the native ethnic group according to the conclusions.

Key Words: historic embroideries, indigenous, Mbayá-Guaycurúe, $18^{\text {th }}$ century.

Recibido: febrero 2018

Aceptado: junio 2018

\footnotetext{
* Este artículo (con ajustes y adaptaciones) es proveniente del proyecto de investigación de tesis doctoral: "La barrera humana: indígenas fronterizos y pioneros coloniales en la raya del Mato Grosso-Moxo-Chiquitano en el siglo XVIII", presentado por el autor en el Programa de Doctorado en Historia de América de la Universidad Pablo de Olavide de la ciudad de Sevilla (Andalucía - España).

${ }^{* *}$ Ney Alves de Arruda es profesor brasileño, natural de la ciudad de Cuiabá. Es doctor en Historia de América por la Universidad Pablo Olavide de Sevilla (Andalucía - España). Profesor de la UFMT - Universidad Federal del Mato Grosso, desde 1992. Maestría por la Universidad Federal de Santa Catarina. Diploma de "Estudios Avanzados" (Maestría) por la Universidad de Burgos (Castilla y León - España). Es profesor de Historia de las Instituciones Jurídicas en la Facultad de Derecho (UFMT). Dicta clases en la Facultad de Comunicación y Artes de la UFMT. También es profesor voluntario invitado de violín en el Programa de Extensión de la Pro-Rectoría de Cultura: "UFMT con la cuerda toda". Inscripto en la Orden de los Músicos de Brasil. Miembro del Colegio de Abogados OAB Seccional del Mato Grosso. Tiene 144 artículos publicados en el periódico "Diario de Cuiabá". Desarrolla estudios sobre: Teoría Crítica, Historia, Arte, Estética, Cultura y Música. Contacto: neyarruda@gmail.com
} 


\section{La existencia de muchas naciones autóctonas en la región central de la frontera colonial hispano-lusa: los Mbayá-Guaycurú como una nación indígena rayana en destaque}

Como un necesario exordio importa expresar que se reconoce desde el punto de vista metodológico, la América del Sur en el siglo XVIII, considerando un recorte geográfico central de la región bañada por los ríos linderos Paraguay, Cuyabá, Guaporé, Madeira y Mamoré que presentaron en sus barrancas una profusión de naciones indígenas a seguir consideradas con especial matice a los Mbayá-Guaycurúe.

Interesa un entendimiento preliminar acerca de las naciones que habitaban en un área del Gran Chaco central, esto es zonas que hoy pertenecen a territorios de Bolivia (Provincia de la Chiquitania y Departamento de Beni en la región de Moxos), Paraguay (borde limítrofe con Brasil donde transitaron y vivieron los indios Payaguá), y por fin, la línea lindera del actual estado brasileño del Mato Grosso con Bolivia, justamente uno de los caminos más importantes de circulación nómada de los indígenas Mbayá-Guaycurúe. Esta área tiene proximidad con los ríos colindantes mencionados que registraron históricamente uno de los marcos rayanos originales entre las dos formas de acción colonial: o sea, una franja en materialización de la frontera central hispana y lusitana colonial permeada por naciones de naturales en el siglo XVIII.

Una posible metodología de investigación para constatar alguna parcela de la realidad histórica de esos agrupamientos humanos nativos, fue su catalogación por específicos troncos de habla originaria. La clasificación de las poblaciones del área chaqueña rayana se basa en el término lingüístico, esto es, un índice con coherencia para identificar la aglomeración de las tribus componentes. Branislava Susnik ha justificado la procedencia de este método clasificador por los bloques de lenguaje nativo, cuando enfatiza que una familia lingüística generalmente representaba también el elemento étnico predominante y una cierta homogeneidad del patrón cultural fundamental, aunque los diferentes contactos culturales, precolombinos (arawak, subandinos, mattogrossenses), y postcolombinos, circunstanciaron algunas manifestaciones peculiares de varios grupos tribales, permitiendo éstas hablar de un "complejo cultural chaqueño" ${ }^{1}$.

Justamente en el denominado por Susnik como 'complejo cultural chaqueño' se operó nuestro interés en una aproximación investigativa delante de los múltiples grupos étnicos y naciones indígenas haciendo entonces, específico destaque a los Mbayá-Guaycurú. Esto, por ellos representaren ejemplo de una original existencia cultural humana nativa, conteniendo diferentes tipologías de reacción interactiva (o belicosa) a la presencia del agente colonial ibérico, en el marco del siglo XVIII.

Con absoluta procedencia, el científico brasileño explorador rayano Alexandre Rodrigues Ferreira escribe, en sus relatos de viajes, entre los años de 1783 hasta 1791, hecho por las

\footnotetext{
${ }^{1}$ Susnik, Branislava. 1970. Apuntes de Etnografía Paraguaya, Asunción, Manuales del Museo Etnográfico Andrés Barbero, p. 1.
} 
fronteras coloniales luso-españolas, acerca de algunas naciones indígenas en el siglo XVIII que vivieron a lo largo de los ríos Guaporé-Madera, a saber: "Curicharas, Amios, Mabiús, Japurá, Parecis, Kautarios, Corumbiaras, Ariscurosos, Lambis, Kutrias, Karipunas, Patitis"².

La región fronteriza de la Capitanía General lusa del Mato Grosso colonial sintetizó en el siglo XVIII la expresión de los movimientos de expansión luso-paulista en el extremo este de la nombrada América portuguesa. Así que esos territorios rayanos fueron también región de hábitat natural de muchas naciones indígenas cuyas zonas de dominio hacían límites con el antiguo Mato Grosso luso colonial. Maria da Glória Porto Kok identifica algunas tribus de naturales rayanos. Escribe Porto Kok con soporte en textos de investigaciones geográficas que el trazado de los ríos fue siendo detallado, más allá de la rica vegetación, múltiples relevos y esos territorios fronterizos, hasta entonces, inexplorados y desconocidos.

Según esta historiadora, estudios localizaron vestigios de los siguientes grupos indígenas en la región chaqueña central, tales como: "Arahés, Guapindayé, Tapairapê, Xavante, Guacuruaguá, Corumbaré, Carayas, Bororó, Cayapó, Payaguá, Guaycurú" ${ }^{3}$.

A su vez, en las actas lusas del Senado de la Cámara de la Villa Real de Buen Jesús del Cuyabá, constan anotaciones acerca de que existieron naciones indígenas, todas exterminadas por las violentas expediciones de exploración hechas por los "bandeirantes" (exploradores) luso-paulistas y mamelucos que mataron nativos de las naciones Corayás, Pacoacentes, Xiribis, Axanés, Porrudos, Aragoarés, Popucunes, Arapocunes, Mocor, Boripocunes, Itilapores y Goatós. Según transcripciones en paleografía de estos manuscritos del año 1719:

"El capitán-mor Paschoal Moreira Cabral en búsqueda de esclavizar el indio Coxiponés, en una de sus banderas [expediciones], subió el río 'Coxipó' llegando en la región conocida entonces como aldea de la 'Forquilla' dónde arrestó muchos nativos y allí constataron que ellos quedaban con bastante muestras de oro en sus 'botopuis' [adornos]. Por el término de certificación de 08 de abril de 1719, el capitán-mor Paschoal Moreira Cabral solicitó a la Corona de Portugal la fundación de las Minas del río Cuyabá” ${ }^{4}$.

Tal vez éste sea el documento histórico más antiguo que enmarca el avance ilegal luso por tierras españolas desde el Tratado de Tordesillas. Pero la importancia de algunos ríos ha sido transcendental como marco geográfico delimitador de zonas de influencia entre naciones indígenas y acciones del agente colonial ibérico. Como se sabe, una montaña, un lago, en fin,

\footnotetext{
${ }^{2}$ Rodrigues F., Alexandre. 2008. Viagem Filosófica (pelas Capitanias do Grão-Pará, Rio Negro, Mato Grosso e Cuiabá), Manaus, Editora Vader, pp. 177/179 - (traducción libre de los escritores en lengua portuguesa, incluso los siguientes para el castellano del autor de este artículo).

${ }_{3}^{3}$ Porto K., Maria da Glória. 2009. “Os Kaiapó, os Mbayá-Guaicuru e os Payaguá nos desertos, ainda indecisos, pela linha imaginária (Século XVIII)", en Anales del VIII Reunión de Antropología del Mercusur 'Diversidad y Poder en América Latina', Buenos Aires, edición Mercosur, p. 11.

${ }^{4}$ Takamoto S., Yumiko. 2007. Annaes do Sennado da Camara do Cuyabá (1719 - 1830), (traducción y organización de Yumiko Takamoto Suzuki), Cuiabá, Editora Entrelinhas, p. 46.
} 
cualquier paradigma de accidente geofísico servía para demarcar territorios. Y con los ríos no fue distinto, y así se percibe la influencia de cursos de agua como el río Paraguay siendo entonces valioso divisor de tierras y creador de fronteras incluso en siglos coloniales. Galera Gómez, al mencionar la increíble extensión del territorio de dominio de los Mbayá-Guaycurúe, citó algunas veteranas naciones indígenas de la región chaqueña. Subraya él que de este a oeste ocupaban el espacio que había entre el río Paraguay y la tierra alta y montuosa que media entre dicho río y el Paraná, cuyo espacio encerraba los mejores yerbales y tierras que había desde allí hasta Buenos Aires, en las cuales hubo en otro tiempo los pueblos de indios nombrados como: "Ipané, Guarambaré, Perico, Atyra, Caaguazú, Agraranamby, y Xerez" ${ }^{5}$.

Con la delineación de tantas naciones indígenas rayanas existentes en las regiones del Chaco y central luso-brasileña del siglo XVIII, conviene destacar la lección presentada por Carlos Garavaglia y Juan Marchena acerca de algunas características históricas esenciales de la población nativa colonial:

"En otras regiones, como la gran meseta central, la caza y la recolección constituían las actividades fundamentales. Pero, hay que considerar, [...] que los mundos indígenas brasileños no constituyeron en general sociedades pequeñas, aisladas, encerradas o completamente autónomas. Estuvieron ligadas por lazos de parentesco, de intercambios o de guerra, mediante los cuales entraron en contacto grupos apartados y áreas distantes. Diversos especialistas han estudiado las complejas relaciones entre las sociedades indígenas andinas y las amazónicas" 6 .

De hecho, la comunicación fue muy significativa entre las patrias nativas en las fronteras centrales de América del Sur colonial. Pero, un poco más distante de estas añejas etnias naturales de la región chaqueña, constatase una particular característica histórica de las naciones indígenas cuya trayectoria de existencia se desarrolló más allá de su tierra natal cuestionando la frontera impuesta por los colonos y autoridades hispanoportuguesas. Es importante considerar que la región chaqueña fue un área de características muy particulares dentro del sistema colonial. Florencia Sol Nesis apunta que las poblaciones que vivían en su interior, en especial los grupos que adoptaron el caballo como los nativos "Mocoví, Abipones, Tobas y Mbayá-Guaycurú"7, lograron mantener su autonomía por más de tres siglos.

En esto, la importancia del caballo como instrumento de defensa territorial para muchos grupos humanos indígenas se presentó como factor elemental. Pero en esta introducción de las posibles naciones de originarios que habitaron la gran región central chaqueña, en

\footnotetext{
${ }^{5}$ Galera G., Andrés. 1990. Descripción General del Paraguay de Félix de Azara, edición, introducción y notas de Andrés Galera Gómez, Madrid, Alianza Editorial, p. 122.

${ }^{6}$ Garavaglia, J. Carlos; Marchena F., Juan. 2005. Historia de América Latina - De los orígenes a 1805, Volumen II, Barcelona, Crítica S.L., p. 373.

${ }^{7}$ Sol N., Florencia. 2005. Los grupos mocoví en el siglo XVIII, Buenos Aires, Sociedad Argentina de Antropología, p. 13.
} 
específico de la nación Mbayá-Guaycurú, con fundamento en la autora Branislava Susnik, la cual se pone en armonía con las constataciones de Florencia Sol Nesis, se observa la homogeneidad del tronco lingüístico como circunstancia por la que se introdujo en la etnología la clasificación: pueblos de la familia lingüística 'Guaycurú', como fueron los "Abipones, Toba, Pilagá, Mocoví, Mbayá, Payaguá y, probablemente, Guachíes". ${ }^{8} \mathrm{Y}$ aquí se puede registrar que fueron tan grandes y magníficos estos grupos étnicos nativos - que la frontera política en construcción (esto es, la línea rayana) entre españoles y lusos -, repercutió por cortar varias veces los territorios de estas naciones indígenas.

En la región del Chaco (hoy conocido como el Pantanal brasileño y boliviano) que comprendía en aquel momento tierras centrales alagadizas y desconocidas, la competencia de los grupos humanos fue enmarcada por una particularidad antropológica en especial, o sea: la destreza en mantenerse en constante movimiento territorial. Así que nativos de los grupos Mocoví, Tobas, Abipones, Payaguás y Mbayá-Guaycurú constituyeron los grupos integrantes de lo que hoy se considera la categoría lingüística guaycurú. Mientras ellos adoptaron una economía basada en la caza y la recolección con una amplia movilidad, otros grupos de la región como "los 'Lules', 'Vilelas', 'Mataguayos' (pertenecientes a otras familias lingüísticas) desarrollaron prácticas agrícolas y tuvieron desplazamientos un poco más reducidos" ${ }^{9}$. Es posible reconocer que la metodología científica de estudio de los grupos indígenas coloniales basado en la identificación de las clases lingüísticas presenta buenas posibilidades para una investigación multidisciplinar, pues hace viable lecturas interpretativas históricas y antropológicas por esta clasificación de los grupos naturales de la frontera central en América del Sur. Ahora, para explicar los flujos de circulación y amplitud territorial, se puede considerar que algunos fueron grupos indígenas cazadores acostumbrados con largas caminadas de considerables días por florestas, regiones húmedas y márgenes de los ríos. De esta forma, es aceptable que tribus sedentarias de indios que se dedicaron al cultivo de la tierra acabaran por ocupar pequeñas porciones de territorios.

Esta neta capacidad de desplazamiento tribal garantizó la ocupación de extensas zonas territoriales muy considerables en el siglo XVIII. Enfatícese esta competencia de los nativos Mbayá para cambiar de sitio en perdurable oscilación zonal. Señálase que así como los "Kayapó", los Mbayá-Guaycurúe, de la familia lingüística ${ }^{10}$ "Mbayá", conocidos como indios caballeros, fueron las tribus más extensamente distribuidas en la parte meridional y central del Chaco, que comprendían los “Abipón, Mocoví, Toba, Pilagá, Payaguá y los Mbayá"

\footnotetext{
${ }^{8}$ Susnik, B., 1970. Apuntes de Etnografía Paraguaya, p. 5.

${ }^{9}$ Sol N., F., 2005. Los grupos mocovi en el siglo XVIII, p. 51.

${ }^{10}$ Garavaglia, J. Carlos; Marchena F., Juan. 2005. Historia de América Latina, pp. 370 y 372 . Estos historiadores aseveran que: "si nos atentemos al criterio lingüístico, las principales familias o troncos lingüísticos [...] fueron los tupi-guaraní, los gê, [...] los arahuanos, los caribes y los de habla pano."

${ }^{11}$ Porto K., M. da G. 2009. “Os Kaiapó, os Mbayá-Guaicuru e os Payaguá”, p. 3.
} 
Con certeza, fueron decenas de naciones indígenas que vivieron en la región fronteriza central en América del Sur colonial del siglo XVIII. De hecho, los investigadores Carlos Garavaglia y Juan Marchena hacen una indispensable reflexión apoyando este debate. Para ellos:

"En el interior, en la inmensa meseta central brasileña que ocupa desde el Paraguay hasta la cuenca del Amazonas, los 'gê' constituyeron los grupos más numerosos. Conocidos más tardíamente que los tupí costeros, conformaban un variado conjunto de etnias de mil nombres y localizaciones: chavantes, timbira, akwen, coroado, aimoré, botocudo, guaicurúes, purí, tapúia, canela, krahó, cariri, cayapó, apinayé, gorotire"12.

Por otro lado, cercanamente al largo del río Mamoré en la región del actual departamento de Beni (actual frontera más al norte de Bolivia con los estados de Mato Grosso y Rondónia Brasil) convivían algunas etnias nativas formadas por grupos menores cuya lengua era común. De estos grupos, los más destacables fueron los Moxos y los Baures, ambos con lenguas del tronco lingüístico de origen 'arawak'. Otras cuatro naciones indígenas importantes eran los Cayubaba, Canichana, Movima y Itonama. Informa Victor Hugo Limpias Ortiz que una vez que los diferentes pueblos que conformaban la nación de Moxos, "tuvieron los primeros contactos con los españoles, prevaleció su nombre para denominar a toda la región como el área moxeña"13. No obstante la constante circulación de grupos indígenas Mbayá-Guaycurúe por toda esta región rayana.

En las argumentaciones siguientes serán estudiados algunos componentes fundamentales del punto de vista etnohistórico de la nación indígena de los Mbayá-Guaycurú, siendo una de las culturas originales de substancial contribución, por las características históricas investigadas, de la frontera oeste central luso-hispana de América del Sur en el siglo XVIII.

\section{Presencia de los Mbayá-Guaycurúes en la raya histórica}

¿Quién han sido esta raza de nativos inquietos? Los Mbayá-Guaycurúe se destacaron por la gran habilidad y resistencia física, sus incesantes correrías. Ellos fueron, como la mayoría de las tribus guerreras, concientes del valor que representaba la resistencia física, y la fomentaban, según "su criterio cultural con diferentes prácticas físico-ceremoniales y prescripciones alimenticias" 14 .

Una de las más considerables naciones indígenas que habitaron la región central chaqueña de América del Sur entre los ríos Paraguay, Cuyabá, Madera, Guaporé fueron los "Guaycurúes" (también con la grafía "Guaycurú" o "Guaykurú"). Esta nación, igualmente reconocida por designación "Mbayá-Guaycurúe", vivía en general por la zona rayana central suramericana, la

\footnotetext{
${ }^{12}$ Garavaglia, J. Carlos; Marchena F., Juan. 2005. Historia de América Latina, p. 377.

${ }^{13}$ Limpias O., Victor Hugo. 2007. "Misión de Moxos", en APUNTES: Revista de Estudios sobre Patrimonio Cultural, vol. 20, número 1, Bogotá, Pontificia Universidad Javeriana, p. 70.

${ }^{14}$ Susnik, B., 1970. Apuntes de Etnografía Paraguaya, p. 21.
} 
cual sirvió del escenario histórico de las disputas y relaciones hispanoportuguesas en el siglo XVIII. En los comienzos de ese siglo, las parcialidades Mbayá tenían ya sus hábitats definidos. Es posible entender que los "Mbayá" conocían muy bien esos territorios centrales fronterizos para organizar sus propias expediciones de exploración y reconocimiento. Susnik esclarece que los nombres de las parcialidades traducen las características naturales del ambiente, a semejanza del patrón denominador de los Comidí-Guaycurú (Abipones) y a diferencia de las denominaciones Ntokowit-Guaycurú (Toba), basadas éstas en nombres de animales, pájaros en particular. En todos los nombres "se encontraba presente el sufijo '-egodí-egodégi', con el significado de 'los habitantes de', 'los que son de'”'15.

Los Mbayá-Guaycurús han sido esta nación indígena, que por sus parcialidades Tobas y Abipones, estuvieron en la zona colindante histórica integrando a su forma, el concepto de hombre de frontera ${ }^{16}$, esto es, el tipo humano nativo o pionero que habitó participando del proceso colonial de consolidación de la raya luso-española del siglo XVIII. ¿Pero quién son estos hombres pioneros de frontera? Fueron los agentes de colonización de las coronas ibéricas (banderantes, misioneros, burócratas, comerciantes, militares y aventureros) y los originarios indígenas de la región, en particular los Kayapó meridionales, que ocupaban el sureste del Mato Grosso hasta la embocadura del río Araguaya. Más allá de los Mbayá-Guaycurú, distribuidos en la parte meridional y central del Chaco y los Payaguá, que dominaban los ríos Paraguay y Cuyabá. En las inciertas fronteras coloniales, eses "grupos indígenas articularon estrategias políticas y comerciales de alianzas y disensiones extremamente versátiles" ${ }^{17}$. No es un exagero de interpretación destacar históricamente que hubieron acciones indígenas hechas en conjunto con los colonos ibéricos. En verdad, las parcialidades originarias obtuvieron un protagonismo intenso en el proceso histórico desarrollado en la zona fronteriza aquí considerada.

La situación es que la historia de la línea de borda colonial se tornó riquísima por las relaciones cooperativas y contiendas que serían enlazadas en la región, tanto que en el contexto colonial ibero-amerindio se forjaron nuevas identidades indígenas en el trato con los colonos, con las autoridades representantes de las coronas ibéricas y los múltiples grupos amerindios. En cuanto seguía irrumpiendo, en el espacio suramericano céntrico, un conjunto de acciones no articuladas, pero "aguerridas de resistencia india a la presencia de los blancos colonos, la invasión de las tierras y la esclavización al largo de todo el siglo XVIII"18.

Es notable la intervención de los indígenas Mbayá-Guaycurúe en la naciente vida colonial de la región fronteriza hispanoportuguesa. Pero esto no libró los Mbayá de las persecuciones

\footnotetext{
15 Ídem, p. 10.

${ }^{16}$ Turner, Frederick J. 1991. "El significado de la frontera en la Historia americana", en Estudios (Nuevos y Viejos) sobre la Frontera, Solano, Francisco; Bernabéu, Salvador (Coordinadores), Madrid, Centro de Estudios Históricos, p. 16. "Frontiersmen": expresión conceptual histórica de Frederick J. Turner.

${ }^{17}$ Porto K., M. da G. 2009. “Os Kaiapó, os Mbayá-Guaicuru e os Payaguá”, p. 1.

18 Ídem..
} 
forjadas por las autoridades ibéricas. Recordase que entre los años 1626-1660, los informes presentan cuantiosas marchas contra los Guaycurúes y ‘Payaguáes’ (los Payaguá). La ubicación de los lugares en donde los expedicionarios hispano-guaraníes iniciaban rastrear las 'huellas' de los Guaycurús indican particularmente las zonas del río Verde, del río Montelindo y del río Siete Puntas. Sugestivo apunte es que los españoles habían entonces celebrado una alianza con las parcialidades de la nación indígena Guaraní para dar combate a los Guaycurú y Payaguá. Destáquese que la ciudad de Asunción seguía en esos años bajo la constante amenaza de agresiones y ataques Guaycurúe. Para Susnik todo indica que se trataba de "la parcialidad 'Piquayiqui' y algunos subgrupos desplazados de los 'Napipinyiquis', continuando la tendencia de hostilidades por razones de subsistencia" ${ }^{19}$.

Allí se presentaba la situación de los indios de tener establecido los territorios de caza y pesca entre las naciones indígenas que, ante el empuje del proceso colonial ibérico, resultaban en esta zona por propagar la rivalidad de los "yiqui" con los "yegi", parientes tribales, concluyendo casi siempre con la victoria de los Mbayá. Así que sucedió el característico transcurso de refundición de los grupos raciales entroncados, o sea, "la comunidad que sufrió el revés de la refriega intergrupal, quedaba incorporada en la parcialidad o en el grupo de los vencedores con derecho de igualdad étnico-social" ${ }^{20}$.

\section{El belicismo del nativo Mbayá-Guaycurúe}

El área limítrofe entre el mundo español y el mundo portugués en América del Sur colonial, más allá de esas anexiones étnicas impartidas de las disputas grupales, reservaba otros detalles pasmosos. Pues los Guaycurúes practicaban invasiones en contra de las misiones jesuíticas, cuando muchas quedaron arruinadas. Pero lo peor de todo, es posible que los indios también tengan aprendido una lección dramática con los mamelucos paulistas y sus jefes, los banderantes portugueses. ¿Qué han asimilado? Es probable que la acción paulista enseñara a los "Eyiguayegis" un nuevo valor de los cautivos-esclavos, o sea, como un bien de permuta. Así se comenzó delinear el "pathos Mbayá de un destino 'destructor', el Mito Mbayá de una necesidad de 'conquistar tierras' y destruir gentes" ${ }^{21}$. Pero las acciones Guaycurúes (exceptuando las disputas étnicas internas), posiblemente tienen que ser interpretadas también como una reacción a la presencia invasora del pionero hispano-portugués en esto territorio rayano.

En el raciocinio de la historiadora Porto Kok, la alborada del siglo XVII fue el marco temporal cuando empezaron las ferocidades de colonos blancos contra las poblaciones indígenas. Sin duda, un hecho que repercutirá incluso en el siglo XVIII. Y esto se inaugura hacía más de dos mil

\footnotetext{
${ }^{19}$ Susnik, B., 1970. Apuntes de Etnografía Paraguaya, p. 5.

${ }^{20}$ Ídem, p. 6.

${ }^{21}$ Ídem, p. 9.
} 
kilómetros, por lo tanto, muy lejos de la aún variable frontera luso-española, ya que al paso de los años, el proceso de agresión a los naturales acaba, de igual forma, por llegar en la región del Chaco y Mattogroso. Avanzaron desde las tierras sureñas de la Capitanía de las Minas Generales (el actual Triángulo Minero brasileño), llegando en la embocadura del río Araguaya. La bandera lusitana comandada por "Garcia Rodrigues Velho en 1612, estampó para los Kayapó el inicio de una fase de franca hostilidad de los lusos paulistas, agitada por la espoliación de las tierras indígenas por los portugueses y mamelucos" ${ }^{22}$. En poco más que cien años los lusos habrían exterminado, mejor asesinado, una incalculable cantidad de naciones y parcialidades nativas del mundo Indígena brasileño hasta llegar a la raya española.

Esta política ofensiva del proceso colonial ibérico cuando alcanzó la región de los ríos limítrofes de la bacía del río Paraguay, hace con que dos de las más importantes naciones indígenas del territorio rayano busquen refuerzo en antiguas alianzas del pasado, planificando nuevas estrategias belicosas. De esta manera es que se extendió el área de las piraterías payaguá hasta Asunción, restableciéndose además una comunicación más estrecha con el grupo de los Payaguá sureños, los "Evuevís" que también "concertaban coaliciones con los Yiqui-Guaycurú para mayor eficiencia de asaltos a los pueblos coloniales (expediciones 1616, $1623,1660)^{\prime 23}$. De esa forma histórica y originariamente, los Guaycurúe y los Payaguá estuvieron juntos en algunas luchas contra los ibéricos desde la mitad del siglo XVII, llegando estas asociaciones hasta el siglo XVIII. ${ }^{24}$

No obstante este clima de acuerdos para agredir, que fueron celebrados entre las naciones indígenas, y por lo tanto, para hacer la guerrilla chaqueña contra las poblaciones coloniales hispanoportuguesas, implicaron una situación de inseguridad entre ellos. El cambio principal del módulo cultural de los Payaguá se expresaba en la nueva pauta de conducta propia de los canoeros-piratas, asaltantes y practicantes de trueque. Susnik informa ya en el año 1622, las desenvolturas que los indios Payaguá tenían para mercadear sus cautivos en la ciudad de Asunción. Los propios Mbayá se servían de los Payaguá en ocasiones favorables de permuta. Este comerciar no influyo en su modo alimenticio, pues "siguieron siendo pescadores, recolectores y cazadores. Tampoco acostumbraban mantener los cautivos como sus siervos, exceptuando algunas mujeres guaraníes" ${ }^{25}$. Interesante aquí observar que Guaycurúes y Payaguás, mismo en tiempos de relativa paz entre ellos, incluso hecha por tratados, seguían mercadeando sus cautivos, hijos de sus propias naciones naturales.

\footnotetext{
${ }^{22}$ Porto K., M. da G. 2009. “Os Kaiapó, os Mbayá-Guaicuru e os Payaguá”, p.2.

${ }^{23}$ Susnik, B., 1970. Apuntes de Etnografía Paraguaya, p. 27.

${ }^{24}$ Takamoto S., Y. 2007. Annaes do Sennado da Camara do Cuyabá. Año de 1731, p. 18. En el acta de Senado de la Cámara del Cuyabá para ese año, apuntase que expedición lusa de "guerra justa" en contra el gentío nativo atingió la zona "Aicurú" (Guaycurú) y de sorpresa llegaron decepando manos y orejas de muchos indios, cuando los portugueses les dijeron que mostrasen a sus amigos, los caciques 'Payagoa' [Payaguá] lo que había pasado con quien hiciera táctica de guerrilla contra la Corona lusa.

${ }^{25}$ Susnik, B., 1970. Apuntes de Etnografía Paraguaya, p. 27.
} 
En el año de 1700 los Mbayá-Guaycurús ampliaron las hostilidades contra españoles y portugueses. Los indios Guaycurúes poseían entonces armas bien diversificadas, reflejo del intenso intercambio en las fronteras: "arcos y flechas, purretes y lazos de cuero, remos de canoas aguzados en las extremidades, lanzas, puñales y además de espingardas" ${ }^{26}$. En la llegada del siglo XVIII, la borda central de América del Sur se convierte en un gran centro de intercambio de mercadorías de todas las cualidades. Esto hace con que las naciones indígenas puedan fortalecer sus acervos de armamientos rumbo a la acentuación de la guerrilla contra las autoridades y pueblos coloniales ibéricos. Posiblemente esto pueda demostrar la esencialidad de esta frontera céntrica para la vida nativa en lucha con la vida del pionero colonial.

Pero la violencia y asaltos de los Guaycurúe asumieron, como mecanismo activador, las expediciones de los banderantes y mamelucos paulistas que a lo largo de todo el siglo XVII siguieron aprisionando indios en la región fronteriza. Repercutió la acción lusa en las primeras incursiones Mbayá, cuando en el año 1661 atacaron la Misión Santa María de Fe de Itatí. Las incursiones fueron facilitadas por las precarias condiciones de la provincia: o sea, "fue un eco de la rebelión guaraní del 1644, circunstanciales dispersiones de los Itatí-Guaraníes por los territorios, bosques y florestas vecinas, el fracaso colonizador de Xerez, y las irrupciones paulistas $^{\prime 27}$. Aquí se verificaría un conjunto de episodios históricos que en su sumatoria acabarían por alzar los ánimos de las naciones indígenas donde se cuenteaban todavía los Mbayá-Guaycurú.

Se puede posiblemente razonar que, la acentuación de la presencia del tipo colono ibérico en la zona chaqueña central, cuyo equilibrio entre fuerzas nativas fue muy exiguo, terminó por ampliar el nivel de conflicto entre las naciones indígenas. Ejemplo de esto fue que los:

"Guaraníes aprovechaban las expediciones españolas para conseguir su objetivo tradicional: destruir a los Mbayá-Guaycurúes para asegurar así la estabilidad de sus dominios ribereños y de sus campos de cultivo" ${ }^{28}$.

De esta manera, la política de penetración de la corona ibérica en la zona central indígena de América del Sur, sembró la aguda agresión entre etnias distintas, incluso por conmociones de resarcimiento. Unos contra los otros. La guerra de fratricidio entre las naciones originarias estaba lanzada a las puertas del siglo XVIII. Los "Yiqui- Guaycurú" y los Yaporúes se vengaron al participar de la expedición punitiva contra los Guaraníes rebeldes. Las cabelleras guaraníes fueron así objeto simbólico de danza guerrero-ceremonial de los "Yiquis-Guaycurúes". A punto de comprobar que el territorio y el ímpeto guerrero de los Guaycurúes no podría ofrecer ventajas inmediatas "el interés colonial se limitó a las normas de vecinos pacíficos y de expediciones punitivas, practicadas según la conducta circunstancial guaycurú, ésta siempre

\footnotetext{
${ }^{26}$ Porto K., M. da G. 2009. “Os Kaiapó, os Mbayá-Guaicuru e os Payaguá”, p. 4.

${ }^{27}$ Susnik, B., 1970. Apuntes de Etnografía Paraguaya, p. 8.

28 ídem, p. 4.
} 
con patentes intereses socio-económicos" ${ }^{\prime 29}$. Fíjese que el pretexto para el ataque de las llamadas expediciones punitivas estaba en el procedimiento guaycurú, hecha de una forma intimidadora y arrogante de las autoridades coloniales.

Mismo delante de las acciones brutales practicadas por las autoridades ibéricas, los Guaycurué seguían su instinto guerrero de someter la región. Así es que dominaron los poblados de los indios Guaná y aun pasaron más al norte, de donde, atravesando el río Paraguay, arrojaron de sus riberas del este, a los pueblos que los españoles habían formado con indios Itatines y Ñuara, cuyas reliquias existen hoy en Santa María de la Fe y en colonias, como también en el de San Francisco Xavier de los Chiquitos. Los Mbayá-Guaycurúe no pararon ahí sus conquistas, "sino que sin apartarse mucho de la costa oriental del río Paraguay se establecieron y, a fuerza de armas, ganaron todo lo que había desde el río Mandubirá para el norte, matando muchos españoles y guaraníes" ${ }^{30}$. Históricamente el río Paraguay fue la fortaleza de los indios Payaguá, pero no se puede borrar de la memoria el ímpetu y el desempeño de la nación Guaycurúe en todo el curso de este importante río fronterizo en el siglo XVIII.

\section{Hechos de la vivencia guerrera Guaycurúe}

Un dato interesante es que las naciones indígenas chaqueñas de la franja media suramericana adoptaban cierta época para pelearen entre sí y contra los colonos ibéricos. Los "YiquisGuaycurúes previnieron la crisis de subsistencia de sus comunidades, pues una expedición punitiva caería en la época de madurez de frutos cuando la paz había de ser indispensable" ${ }^{31}$. En realidad, observando el objetivo de los naturales de buscar frutos en los bosques y florestas, fue útil una relativa armonía que debería ser garantizada entonces por cierto tiempo.

Por alguna necesidad de fijación territorial para caza y el constante desplazamiento Guaycurúe, es comprensible pensar en situaciones históricas de relativa paz fundadas en la dispersión para averiguar alimentos. Pues, teniendo en cuenta las pautas de movilidad y territorialidad, quienes sostienen que los refriegues intergrupales se habrían producido por el acceso a los recursos. Luego, la necesidad de aprovisionamiento de las tribus hacía que las agrupaciones nativas quedasen un poco más dispersas, y así no había tanto el riesgo del conflicto. En cambio, durante los momentos de aglutinamiento de las parcialidades nativas, "se activaban redes de alianzas y enemistades, y podrían haber constituido los momentos de mayor fricción interracial, la concentración de la población y la efervescencia ritual de la primavera permitieron la realización de empresas colectivas de mayor envergadura, como la guerra" ${ }^{32}$. Los

\footnotetext{
${ }^{29}$ Ídem, p. 04.

${ }^{30}$ Galera G., A. 1990. Descripción General del Paraguay, p. 121.

${ }^{31}$ Susnik, B., 1970. Apuntes de Etnografía Paraguaya, p. 4.

${ }^{32}$ Sol N., F., 2005. Los grupos mocovi en el siglo XVIII, p. 69.
} 
ritualismos de la primavera representaban una época del año para el acercamiento, incluso disputas y conflagraciones intertribales.

Otro medular segmento de la nación Mbayá-Guaycurúe fue representada por los Guetiadegodís, (esto es, los "Montaraces"), que personificaban la parcialidad Mbayá más septentrional en las barrancas crecidamente occidentales del rayano y histórico río Paraguay (Alto Paraguay, al este de la Provincia de Chiquitos). Esto es, con fundamento en Branislava Susnik es permisible madurar que esta parcialidad Guaycurú quedó en la región de la frontera del Mato Grosso antiguo que ha sido gobernada por las autoridades lusas. De forma muy curiosa estos Guaycurúes mantenían relaciones de amistades en ámbito diplomático con algunas naciones indígenas de la zona colindante chaqueña, así como actitudes de opresión con otras. Pues estos 'Montaraces' tenían por su zona de incursión diferentes pueblos de la provincia de Chiquitos. De la misma manera, algunas comunidades Bororó (Otuquis-Bororó) fueron víctimas de la "caza de cautivos". Por otra parte, los Montaraces mantenían relaciones amistosas con los Guachíes de la región pantanosa alto-paraguayense, proveedores principales de arroz silvestre. En los alrededores de esta parcialidad haldeaban los vasallos Poké-Tereno y Kinikinao (Guaná-Arawak). Por acondicionamiento ambiental, los Montaraces solían ser también buenos pescadores y se volvieron rápidamente canoeros durante la confederación Mbayá-Payaguá, índice de que su patrón cultural ecuestre no fue tan pronunciado como entre otras parcialidades Mbayá. “Culturalmente, los 'Guetiadegodís' estaban expuestos a las influencias mattogrossenses por algunos ocasionales hallazgos de cerámica" ${ }^{33}$. Como se puede verificar, estas interpretaciones históricas demuestran la gran capacidad de adaptación de esta parcialidad Guaycurú, tanto en cuestiones de supremacía territorial en atritos de fuerza o diálogos de paz con distintas naciones nativas locales y medios de supervivencia aprovechando los recursos de los ríos para alimentarse.

Las investigadoras Susnik y Sol Nesis comparten de la opinión que, la gran nación MbayáGuaycurúe, en muchas de sus parcialidades, supo sacar provecho de la cuestión geográfica para mantener el control bélico de la región limítrofe chaqueña, una vez que la caza y la recolección sustentaron a los pueblos guaycurú, no solo en el plano de la provisión para el mantenimiento "sino que también permitieron la configuración un determinado tipo de organización social y un modo de relación entre ellos mismos y con sus vecinos caracterizado por las luchas interparciales" ${ }^{\prime 34}$. En realidad, la competencia y habilidad para hacer la guerra de los Guaycurúes permitió la construcción de una cierta hegemonía indígena fortalecida en la zona rayana que se

\footnotetext{
${ }^{33}$ Susnik, B., 1970. Apuntes de Etnografía Paraguaya, pp. 10- 11.

${ }^{34}$ Sol N., F., 2005. Los grupos mocovi en el siglo XVIII, p. 51.
} 
tornó algo un tanto dura de romper para las autoridades coloniales tanto españolas como portuguesas. $^{35}$

No se puede olvidar que uno de los componentes de la naturaleza antropológica del indígena chaqueño rayano en los años coloniales fue la lucha territorial. Ellos vivieron buena parte del tiempo en peleas intertribales. Su "modus vivendi" ha sido claramente la conquista de nuevos territorios de caza y recolección. Esto explica que el abandono colonial de Xerez permitiese aún más la libre expansión limítrofe de los nativos Eyiguayegis. Esta parcialidad indígena, ajustó asiduamente con los Payaguá para invadieren juntos la región de los originales GuarambaréGuaraníes (1674), convirtiéndose entonces, en los señores de la zona Ypanense. Por ejemplo, "esto reflejó que el río Ypané se volvería río Bidioni Taloconagadi según una nueva denominación mbayá" ${ }^{36}$. La liga Mbayá-Guaycurú con los Payaguá en fines del siglo XVII repercutió fuertemente ya en los primeros años del siglo XVIII, porque áreas dejadas sin la presencia militar de las coronas ibéricas, abría paso a acuerdos entre las naciones originarias.

Pero la maliciosa estrategia de los portugueses en poner una nación indígena contra la otra fue algo realizado. Es ejemplo de esto lo que queda registrado en el acta del Senado de la Cámara del Cuyabá para el año de 1740:

“[...] por lo que decía respecto a los 'Payagoa' [Payaguá], de momento la orden es que se mande un oficial Cabo con capacidad de hacer amistad y ofertar regalos a los 'Aicurús' [Guaycurúes] para que por este medio fuesen destruidos aquellos. Finalmente que manden hombres prácticos investigar las 'Poblaciones de Castellanos' más cercanas para con ellos tratar amistad, sin hacer que diesen pavor a los 'Payagoa'”37.

Los pactos indígenas y el constante combate a los pioneros ibéricos hizo que la colectividad fronteriza colonial aún en desarrollo sufriese mucho con las constantes investidas de los grupos nativos consorciados. De hecho, la sociedad hispano colonial no había logrado establecer, hasta entonces, un dominio efectivo sobre estas tierras. Las posibilidades defensivas no daban la contención necesaria frente a los avances de los grupos nativos chaqueños, "lo que queda ejemplificado con el abandono del primer emplazamiento de la ciudad de Santa Fe como consecuencia de las continuas hostilidades" ${ }^{38}$.

La diversidad de naciones nativas enemigas de los Mbayá-Guaycurú fue considerable del punto de vista histórico, a la vez que contra ellos se realizaron algunas expediciones punitivas, solían alardearse de su valor guerrero e invencibilidad en las contiendas con los

\footnotetext{
${ }^{35}$ Amado, Janaína; Caselli A., Leny. 2006. Anais de Vila Bela 1734 - 1789, Cuiabá, Editora Carlini \& Caniato, p. 197. Consta del Acta de Villa Bella de la Santísima Trinidad para el año de 1775, registro acerca de las deserciones constantes de esclavos ("facinorosos") para los dominios de España y los insultos del gentío Payaguá y Guaycurú.

${ }^{36}$ Susnik, B., 1970. Apuntes de Etnografía Paraguaya, p. 9.

${ }^{37}$ Takamoto S., Y. 2007. Annaes do Sennado da Camara do Cuyabá. Año 1740, p. 22 (verso).

${ }^{38}$ Sol N., F., 2005. Los grupos mocovi en el siglo XVIII, p. 14.
} 
Naperúes/Yaperúes, Guatatáes, Agaces e Imperúes. Susnik establece que esta referencia no comprueba la individualidad étnica de los Mbayá-Guaycurúes, pero si la "conciencia de un grupo tribal en su lucha por sostenimiento, por el derecho de explotación de cazaderos y algarrobales en una zona con limitadas posibilidades económicas" ${ }^{\prime 39}$. Pero se debe también considerar al lado de la cuestión de la lucha por la supremacía territorial, el dato referente al cuantioso número de sus parcialidades que, sin duda aclara el potencial agresivo de los Guaycurúe cuando todos estaban combatiendo juntos. Reconózcase tres grupos que componían la "nación” Guaycurú: "Taqui-yiqui'/ Guaycurú, 'Napipin-yiqui'/ Guaycuruti y 'Piqua-yiqui'/ Guaycurú guasú y el cura Sanchez Labrador, historiador de los Mbayá-Guaycurú, discute dicha etnificación y acentúa la homogeneidad étnica 'Eyiguayegui'-Mbayá-Guaycurú" ${ }^{40}$.

\section{La resistencia indígena: el significativo del caballo para los Mbayá}

Si la nación de indios Payaguá tuvieron como valiosa caracterización el hecho de la habilidad con las canoas remando con agilidad por los ríos fronterizos, entonces la identificación de la etnia Guaycurúe se facilitó con los cuadrúpedes. A la vez que la apropiación del caballo venido para las tierras coloniales con los españoles, "posibilitó una nueva ecuación de fuerzas de los Mbayá-Guaycurú delante de otros grupos indígenas y de los ocasionales, sin, entretanto, alterar radicalmente las técnicas y las estrategias guerreras de los amerindios" ${ }^{\prime 1}$. La habilidad guaycurú con las cabalgaduras ha sido tan especial que esto incorporó un temor un tanto mayor en sus contendores coloniales.

El caballo hispano-ibérico, muchas veces fue hurtado de los colonos europeos y ha apoyado de forma sustancial el triunfo en los combates guaycurús de guerra. En realidad el uso bruto de la fuerza de cada guerrero fue fundamental, a la vez que la principal estrategia guaycurú era combatir a caballo en campo abierto con formidables tropas de caballeros. "Cuando avistaban los enemigos, ajuntaban los caballos contornando los lados, los apretaban de tal suerte que, con la violencia con que iban, rompían y atropellaban los enemigos, y estos indios con lanzas mataban cuantos encontraban delante" ${ }^{\prime 2}$. La furia los poseía y cada nativo Guaycurúe se cambiaba un gigantón en el escenario de batalla.

Para tener una idea acerca de la valoración de los cuadrúpedes para los guaycurúes, véase por ejemplo lo que trazan Calvo y Benzi: "el caballo parece ser uno de los elementos más significativos que incorporaron, por cuanto provocó intensos cambios en los planos económico, político, social y en el de las relaciones interétnicas. Dentro de este contexto, los guaycurú supieron aprovechar el desarrollo de las economías coloniales circundantes basadas

\footnotetext{
${ }^{39}$ Susnik, B., 1970. Apuntes de Etnografía Paraguaya, p. 3.

40 ídem, p. 3.

${ }^{41}$ Porto K., M. da G. 2009. “Os Kaiapó, os Mbayá-Guaicuru e os Payaguá”, p.5.

42 'ídem.
} 
principalmente en la ganadería"43. De esto modo, la importancia de las cabalgaduras para los Mbayá, más allá de las guerras, se justifica en el transcurso de la ocupación pionera ibérica que diseñó nuevos retos y nuevas eventualidades al conjunto Guaycurú por el declive de su ambiente natural de caza y cosecha.

Volviendo al tema de las peleas Mbayá, los ataques masivos en batalla campal también cedió paso a otra táctica guerrera, como explica Maria da Glória Porto Kok:

"otro modo de combatir fue la división en varios grupos compuestos por cerca de 40 guerreros indios. Una pequeña tropa se mostraba visible a los españoles que partían en su búsqueda, en cuanto otras pandillas aparecían de lugares distintos. De esto resultaba la división y la completa desorientación de las milicias ibéricas. Con este plan han logrado casi arruinar la provincia del Paraguay por el Oriente y Norte" ${ }^{44}$.

Esto dato refleja la genialidad traviesa de la nación originaria Mbayá-Guaycurúe que protagonizó un destino de bravura y resistencia destacadas en la construcción colectiva de la historia colonial en la frontera central suramericana.

Cerca de la mitad del siglo XVIII, la obstinación de la identidad indígena Mbayá-Guaycurú pierde mucho de su pujanza. En el área chaqueña, los Mbayá se veran amenazados por la creciente penetración de nativos de la Lengua-Cochaboth, Ilamados 'Nogogolodi'. "La inseguridad producida por la vecindad chaco-sureña, graves reveses en la zona chaco-norteña y la continuidad misma de las contiendas disminuyeron la potencialidad guerrera, numérica y física de los Mbayá" ${ }^{45}$. De hecho, la lucha Guaycurú por el control de sus territorios fueron ablandados por la mezcla cultural de otras naciones originarias que sutilmente produjeron una forma de habla nueva. Había también que convivir con los colonos ibéricos tanto lusos como españoles que entonces ya empezaban a habitar la región chaqueña lindante colonial.

En búsqueda inquebrantable de alimentos resultantes de la caza, pesca y colecta de frutos silvestres no se puede registrar con absoluta seguridad que los nativos tuvieron inequívocas prácticas de sedentarismo. Esto es, de establecerse en una región dada y quedarse allí con ánimo definitivo. Los jesuitas misioneros españoles lograron buen éxito en promover un poco de estos hábitos generales en los indios. Es factible suponer que los indígenas se movían constantemente por localidades chaqueñas. Pero sin embargo es viable también pensar que, se tenía interés en cultivar, esto sería en área de considerable identidad cultural y ancestral. Sol Nesis contribuye indicando la importancia de determinar los alcances del nomadismo guaycurú, y así instituye que probablemente el tipo de movilidad de los indios no implicaba el movimiento

\footnotetext{
${ }^{43}$ Calvo, Luís M.; Benzi, Marina. (sin fecha). "Florián Paucke, un austríaco en tierras mocovíes”, en Museo Etnográfico y Colonial Juan de Garay, Departamento de Estudios Etnográficos y Coloniales, Argentina, Provincia de Santa Fe, p. 06.

${ }^{44}$ Porto K., M. da G. 2009. “Os Kaiapó, os Mbayá-Guaicuru e os Payaguá”, p. 5.

${ }^{45}$ Susnik, B., 1970. Apuntes de Etnografía Paraguaya, p. 16.
} 
constante de las agrupaciones con el fin de dominar ciertos espacios sino que, al estar más bien relacionados con la obtención rápida de recursos, podría asemejarse más a vaquerías criollas. "Desde un campamento se realizaban expediciones sobre áreas que eran compartidas por diferentes grupos. Sin embargo, se establece que los guaycurús reclamaban derechos de exclusividad sobre áreas determinadas en las cuales cazaban y recolectaban" ${ }^{46}$. Sugestivo no perder de vista que concurrían fracciones de la región del Chaco que se localizaban bajo el señorío de indios principales de naciones naturales, siendo que esta autoridad implicaba la vigilancia cuidadosa del fragmento elegido de la zona.

Del contacto con los españoles, es incontestable que en la nación Mbayá-Guaycurúe nació un gusto especial y la destreza con los caballos. Pronto estos indígenas cabalgaban con maestría por la zona chaqueña rayana. Y esto garantizó una cierta superioridad que las monturas les proporcionaron.

\section{Por entre secuestros de niños nativos, enfermedades y el comercio Mbayá}

Esta delantera resaltó también por capacitarlos para una crueldad aterradora. Pues los MbayáGuaycurú se pusieron a guerrear contra diversas naciones indígenas de los territorios coloniales. El objetivo de estas conflagraciones amerindias residía en capturar cautivos, principalmente los niños. Aunque fuesen de pecho, se los llevaban y hacían crecer según sus ritos y modales. De ésos tenían muchos de todas edades, hijos de colonos españoles de la ciudad de Asunción, y de la Villa de Curuguatí, como también de otras naciones. "Las mujeres adultas merecían algún interés y entonces cautivaban algunas y otras. Pero, todos los hombres pasaban por los cortes de sus lanzas y alfanjes" ${ }^{\prime 7}$. O sea, una de las principales metodologías para el crecimiento poblacional Guaycurúe quedaba en el secuestro de los pequeños inocentes. Tristemente quitaban los críos de sus familias y culturas propias.

La mitad del siglo XVIII fue un marco temporal importante en la trayectoria de la gente Guaycurúe. En realidad, el arresto de impúberes ha tenido una rentable comercialización, a la vez que los aprisionados compusieron un eficaz impulso mercantil de los Mbayá-Guaycurú en esta época. Pero hay que considerar también que la línea limítrofe de su área para libre circulación se estrechaba drásticamente ante el avance colonizador de los gobiernos locales ibéricos en la frontera. El poder demográfico de los Mbayá decayó notablemente, tanto a causa de continuas guerras, o por epidemias de viruela y también por la práctica social de limitación de nacimientos. Susnik apunta que el cacique principal de los "Guetiadesgodís", el nativo de nombre Golanigi, buscaba cautivos en la Provincia de Chiquitos. Pronto las "milicias neófitas chiquitanas demostraron una tenaz resistencia, pasando a la ofensiva y los Mbayá

\footnotetext{
${ }^{46}$ Sol N., F., 2005. Los grupos mocovi en el siglo XVIII, p. 65.

${ }^{47}$ Porto K., M. da G. 2009. "Os Kaiapó, os Mbayá-Guaicuru e os Payaguá”, p. 5.
} 
experimentarían los primeros grandiosos reveses en sus contiendas" ${ }^{\prime 4}$. Esto explica en parte como empezó la decadencia de la capacidad guerrera Mbayá-Gusaycurú por la cuestión de las enfermedades. De forma especial, reconociese la oposición de las naciones indígenas de Chiquitos ofertando derrota histórica a los Mbayá.

Naturalmente estas acciones esclavizadoras de la etnia Mbayá-Guaycurue buscaban generar algún consuelo (aún que deshumano) en sus comunidades indígenas. Interesante observar el número de naciones naturales esclavizadas, que no fueron pocas. Porto Kok expresa que en sus aldeas vivían indios de las naciones Guaxi, Guató, Cayovaba, Bororo, Coroa, Kaiapó, Chiquito e Xamococo, "que hacían diversas tareas y servicios, como buscar leña, cargar agua, cazar, pescar, hacer pinturas corporales y cultivar la tierra. Explorase el hecho de que los MbayáGuaicurúes más pobres poseían tres o cuatro esclavos" ${ }^{49}$. Por esto, tales niños arrestados de otras naciones desempeñaban labores domésticas para la comodidad de las familias Guaycurúes.

Tenemos muy en claro la importancia de la cuestión histórica pertinente a las epidemias, las cuales causaron de forma continúa la desintegración de las comunidades indígenas independiente de la nación. Sea Payaguá o Guaycurúe las dolencias constituían un motivo aleatorio que planteaba la necesidad de que las agrupaciones se dispersasen en unidades familiares. Sol Nesis argumenta con fundamentada posición de que en su gentilidad, "los indígenas tenían la costumbre, especialmente en tiempos de viruela o de alguna peste. Entonces ni las familias, por veces, quedaban reunidas sino que se dispersaban por los bosques" ${ }^{\prime 50}$. De hecho, se puede localizar distintos momentos del año que ellos lograban armonizarse en desiguales grados de movilidad y desbordamiento también por enfermedades, muchas cogidas del pionero blanco europeo.

Es sugestivo el coloquio acerca de las causas de mayor o menor disposición guaycurú para la conflagración. La hostilidad oscilante de esta parcialidad se debía a algunos factores. Anota Susnik compartiendo los registros de Sol Nesis de que esto correspondía "a continuas contiendas y frecuentes epidemias de viruela que provocaron una importante disminución numérica de los grupos Mbayá” ${ }^{51}$.

Otro punto de destaque son algunas relaciones económicas enmarcadas por una relativa paz con las colectividades hispano-guaraní mediante los trueques ocasionales de auxilios y rehenes detenidos, esto por bienes y utilitarios, sino también de importancia social. De alguna forma, los Mbayá-Guaycurú perfeccionaron su capacidad negociadora de bienes al largo del siglo XVIII.

Interesante que en las actas del Senado de la Cámara del Cuyabá, se encuentran noticias sobre haberse vislumbrado que los Mbayá-Guaycurúe alimentaron algunas relaciones de

\footnotetext{
${ }^{48}$ Susnik, B., 1970. Apuntes de Etnografía Paraguaya, p. 14.

${ }^{49}$ Porto K., M. da G. 2009. "Os Kaiapó, os Mbayá-Guaicuru e os Payaguá”, p.5.

${ }^{50}$ Sol N., F., 2005. Los grupos mocovi en el siglo XVIII, p. 64.

${ }^{51}$ Susnik, B., 1970. Apuntes de Etnografía Paraguaya, p. 5.
} 
cooperación con los españoles. El 04 de octubre de 1776 la expedición militar bajo comando del capitán Miguel Jozé Rodrigues se encuentra en el río Paraguay con numerosos botes de indígenas:

“[...] en la ocasión del comandante hacer algo, percibió que lo mejor para que la escuadra lusa no sufriese daños sería no hacer movimiento algún. Cuando el comandante ha ordenado que uno de nuestros barcos bien armados abriese charla con los nativos llamándolos para quedaren reconocidos. Esto fue aceptado por los indígenas que entonces, por medio de dos barcos bien servidos de gente se acercaron y luego declararon que eran 'Aicurús' [Guaycurúes] y que solo querían mantener amistad con los castellanos, porque los portugueses tendrían armas de fuego y ellos no prestaban para nada. Informado de la situación, el comandante ordenó que se ofreciese algunos regalos a los indios. Momento en que los 'Aicurús' aceptaron las ofrendas y dijeron que tenían muchos caballos y vacas para venta. Dieron gracias y se marcharon" ${ }^{52}$.

En tales condiciones, la competencia negociadora de la parcialidad Guaycurúe también puede que se explique por el considerable número de extranjeros europeos y colonos que habían sido secuestrados en esa frontera central de América del Sur. Porto Kok manifestase acerca de una señora portuguesa ya vieja de la Villa del Cuyabá, que vivía hacía más de dieciséis años en una aldea Guaycurú. Otro ejemplo es de una mujer lusitana, "cuyo marido fue muerto por los indios en el camino del Cuyabá, que ya completaba siete anos entre os amerindios, en compañía de sus dos creados negros y seis cautivas cristianas de Asunción, siendo que una de ellas servía de intérprete, ya que sabia la lengua Guarani" ${ }^{53}$. O sea, es posible que muchos de los extranjeros arrestados trabajaran de forma indirecta para potencializar la aptitud comercial de los Mbayá-Guaycurú. Sin duda, florecieron los Guaycurúes en algunas cuestiones económicas haciéndose habilidosos mercadores.

\section{Presencia Mbayá en las regiones rayanas centrales}

Los Mbayá-Guaycurúe siguieron con sus instintos ancestrales de subyugar a otras etnias indígenas de la gran región limítrofe chaqueña. Por ejemplo, la parcialidad de los Yiquy-MbayáGuaycurúe manifestaba fuerte tendencia belicosa, teniendo los pelos rapados de las cabezas, "lo que simbolizaba la valentía del guerrero. Ellos asumían, sin embargo, la práctica de asaltos periódicos a las aldeas y campos cultivados de los naturales Carió-Guaraní. Estas agresiones exigían el uso ocasional de las canoas para el cruce del río Paraguay" ${ }^{54}$. La rivalidad cultural entre las naciones indígenas del área fronteriza colonial venía de siglos de vecindad entre zonas

\footnotetext{
${ }^{52}$ Takamoto S., Y. 2007. Annaes do Sennado da Camara do Cuyabá. Año de 1776, p. 51.

${ }^{53}$ Porto K., M. da G. 2009. "Os Kaiapó, os Mbayá-Guaicuru e os Payaguá”, p. 6.

${ }^{54}$ Susnik, B., 1970. Apuntes de Etnografía Paraguaya, p. 4.
} 
cazaderas conflictivas. Cuando algunas de las tribus eran asaltadas tendrían que trasladar ante la pérdida de sus pequeños plantíos ya trabajados.

Con razón arguye Sol Nesis que el movimiento de los grupos indígenas puede estudiarse en dos planos: "como movilidad de una agrupación dentro de un territorio y como desplazamiento intergrupal a través de un entramado de relaciones sociales y jerarquías" ${ }^{55}$.

La vecindad cultural entre naturales y blancos pioneros fue algo muy complejo. Las dos naciones indígenas de las más temidas en la raya chaqueña concibieron una guerra heroica de casi medio siglo resistiendo al proceso hegemónico colonizador hispano-lusitano. Porto Kok confirma que en reacción a las acciones coloniales ibéricas en los territorios indígenas, los Mbayá-Guaicurú hicieron histórica alianza con los Payaguá, "entre aproximadamente 1715 hasta 1768 , lo que garantió la superioridad bélica de los amerindios en las guerras contra los españoles, portugueses y otros grupos indígenas en las diversas regiones de la América del Sur meridional" ${ }^{\prime 56}$. En los cerca de 49 años de resistencia es sorprendente apreciar la lucha instintiva de las etnias rayanas nativas en búsqueda de preservar sus propias culturas, sus valores, su forma de vivir en el ambiente en modificación, teniendo en cuenta la frontera que imponían colonos y las autoridades europeas.

El tema de las alianzas entre los Mbayá-Guaycurúe con los Payaguá, (denominados por ellos como Cachomododi), tiene un carácter fuertemente recurrente, pues consiguieron la situación de haber sido considerados como frecuentes, pero en realidad, más circunstanciales en incursiones y asaltos. Rasguea Susnik que las ventajas de las contiendas con canoas, pues que eran bien conocidas por los Mbayá, teniendo éstos cierto recelo al comportamiento tribal de los Payaguá. Esta alianza (1715-1768) dejó su huella en el módulo 'canoero' que integró algunos cacicatos de los Mbayá norteños, favoreciendo un intenso comercio desde el Alto Paraguay hasta Asunción por intermedio de los Payaguá. "Solamente algunas que otras contiendas interrumpían ocasionalmente esas nuevas relaciones socio-económicas de los "Ecalais" (españoles) con los Mbayá y los Payaguá" ${ }^{57}$. Por cierto, los pactos Guaycurú-Payaguá resultaron por fortalecer la movilidad de mercaderías reconociendo en la región bañada por el río Paraguay, como un canal histórico de flujo fronterizo de personas y productos ya en el siglo XVIII.

Las coaliciones entre naciones indígenas suscitaron la reacción de las autoridades gubernamentales coloniales en la región fronteriza meridional, hasta porque había necesidad de que las poblaciones colonas poseyesen un cinturón mínimo de defensa y alguna tropa de soldados. Esto permitiría "en 1710 realizar una expedición que terminó por desplazar a algunas

\footnotetext{
${ }^{55}$ Sol N., F., 2005. Los grupos mocovi en el siglo XVIII, p. 63.

${ }^{56}$ Porto K., M. da G. 2009. “Os Kaiapó, os Mbayá-Guaicuru e os Payaguá”, p. 6.

${ }^{57}$ Susnik, B., 1970. Apuntes de Etnografía Paraguaya, p. 14.
} 
agrupaciones indígenas de la región fronteriza hacia el oriente chaqueño, cerca de las ciudades de Santa Fe y Asunción" ${ }^{58}$.

El avance colonizador después de la noticia de descubrimiento del oro en los primeros años de los 1700 en la región del Cuyabá y de Goiás amplió la resistencia de los Payaguá, Guaycurú y Kayapó en la zona contigua hispano-matogrosense. Como consecuencia de las guerras entre estos grupos y las tropas luso paulistas, "Ias aldeas indígenas se saturaron de cautivos blancos, negros, mulatos, bastardos e indios carijós que hablaban lenguas diferentes $y$, muchas veces, servían de intérprete en el mundo colonial fronterizo chaqueño-lusitano" ${ }^{59}$.

Acerca de un marco temporal, los años iníciales del siglo XVIII son importantes referenciales para constatar que las naciones indígenas chaqueñas marcharon rumbo al conflicto no respetando las urbanizaciones coloniales en la zona fronteriza. La raíz de este desplazamiento, “a partir de 1710 los grupos indígenas chaqueños comenzaron a acercarse a los pueblos rayanos ibéricos, percibiéndose entre 1720 - 1740 un incremento notable de las entradas indígenas sobre las estancias aledañas a las villas y pueblos coloniales" ${ }^{\prime 60}$. En esta atmósfera, los asentamientos hispanos no poseerían cualquier control sobre el área.

\section{Conflictos coloniales de exterminio al gentío Mbayá}

Considerando el tema, un año de relieve es el de 1728, porque desde entonces las autoridades ibéricas y en especial la corona lusa instituyen una política de intolerancia total contra las naciones indígenas en la franja chaqueña. A partir de este año, se tornaron más frecuentes las expediciones punitivas para 'desinfestar' los indios Guaicurú, Payaguá e Kaiapó de los caminos fluviales y terrestres que se irradiaban de las minas de la Villa del Cuyabá y de Goiás. El Rey portugués $D$. João $V$ ordenó dar un castigo que los atemorizase, de modo a que se respetase las armas portuguesas. "De este modo, armas, pólvora, mosquetes, plomos, municiones e más 'apertreches necesarios para tal fin' fueron distribuidos a los integrantes de las tropas, por cuenta de la Real Hacienda" ${ }^{61}$. Se registró recomendaciones para que fuesen atacados dentro de sus acampamientos, así los gentíos Guaycurúes, Payaguá, como también otras naciones confederadas que les ayudasen. Es sugestivo vislumbrar que la corona lusitana había creado una nueva y pretensa "normativa" cruel en la frontera histórica. O sea, el "derecho" de exterminar los indígenas que no hubiese sido posible 'domesticar'. Lisboa no ahorró ninguna moneda, es decir, ningún recurso para armar hasta los dientes las fuerzas militares en la raya hispanoportuguesa.

Desinfestar significaba para las autoridades coloniales lusas en la frontera chaqueña central, sencillamente la idea de aniquilar las poblaciones indígenas. Por esto, los liderazgos Mbayá-

\footnotetext{
${ }^{58}$ Sol N., F., 2005. Los grupos mocovi en el siglo XVIII, p. 14.

${ }^{59}$ Porto K., M. da G. 2009. "Os Kaiapó, os Mbayá-Guaicuru e os Payaguá", p. 12.

${ }^{60}$ Sol N., F., 2005. Los grupos mocovi en el siglo XVIII, p. 14.

${ }^{61}$ Porto K., M. da G. 2009. “Os Kaiapó, os Mbayá-Guaicuru e os Payaguá”, p. 6.
} 
Guaycurúes consideraron la posibilidad de buscar alianzas con otros pueblos como los Payaguá, o con los mismos españoles. Esto fue intentado por primera vez por el cacique principal Epaquini y su sobrino Napidrígi, uno de los frecuentes aliados de los Payaguá. También había el hijo de éste último, Epiliglyegi (Lorenzo), mestizo Payaguá-Mbayá que vivió cierto tiempo entre los Payaguá en las proximidades de Asunción, conociendo así la pauta de conducta entre los Payaguá y los españoles. Así que "las 'paces' (del año 1756) fueron favorecidas por la presencia de un enemigo común: los indios Lengua-'Cochaboth'. El mencionado pacto de amistad no disputó el tradicional límite sureño Mbayá” ${ }^{62}$.

En el horror de la guerra injusta autorizada por Lisboa contra los indígenas rayanos había también los "premios" programados a los vencedores, esto es, lo que lucrarían los participantes de las excursiones de castigo. Eso implicaba en la venta de los indios aprisionados en plaza pública y la distribución de lucros a los colonos pioneros que integraban la expedición punitiva, "desde que fuese debidamente pago el impuesto específico del Real Quinto de su Majestad"63. Además señalar que si los indios se entregaban, serían presos y juzgados, pero si luchaban, serían ejecutados, exceptuando niños con menos de diez años, pues había necesidad de ser cobrado el tributo concerniente en el quinto de la corona lusa.

Las expediciones lusas conocidas como punitivas eran en realidad expediciones de muerte que fueron compuestas por toda clase de grupos étnicos fronterizos disponibles en la raya histórica hispanoportuguesa. Hombres toscos, iletrados y brutalizados por la casi siempre ingrata vida en las colonias rayanas del siglo XVIII. Así estaba la categoría racial de los bastardos, esto es, una terminología en uso en aquella época para designar el mestizo resultante del indio y blanco, cuya situación personal era de ser todos libertos. Más allá del mestizo, las expediciones punitivas eran compuestas también de hombres pardos, o sea, una categoría fenotípica imprecisa para aquellos años, pero que designaba los indios en convivencia con los colonos. "Se podría contar muchos mulatos, estos claramente mestizos afro-descendentes; los prietos y naturales 'Carijós', o sea, nombre general dado al indio colonial; indios considerados "amigos" de los luso-paulistas y por esto deberían vivir en libertad" ${ }^{64}$.

Los hombres pioneros reclutados para formar parte de las expediciones de asesinato indígena ${ }^{65}$, en especial hechas para destruir los naturales Mbayá-Guaycurúes y Payaguá, fueron

\footnotetext{
${ }^{62}$ Susnik, B., 1970. Apuntes de Etnografía Paraguaya, p. 16.

${ }^{63}$ Porto K., M. da G. 2009. "Os Kaiapó, os Mbayá-Guaicuru e os Payaguá”, p. 7.

${ }^{64}$ Porto K., M. da G. 2009. "Os Kaiapó, os Mbayá-Guaicuru e os Payaguá”, p.8.

${ }^{65}$ Assis A., Austin de; Weber, Astor. 2013. "A política luso-brasileira em relação aos Eyiguayegui-Mbayá-Guaicuru na Capitania de Mato Grosso", en Anais do VIII Encontro de Produção Científica e Tecnológica, Universidade Estadual do Paraná, Campo Mourão, Brasil, p. 04. Presentan estos autores lectura histórica válida acerca del tema: "La aproximación de los españoles, que vivían en las tierras de los Guaycurús como ruta hasta el Eldorado peruano (donde acreditaban poder encontrar en abundancia metales preciosos como oro) provocó grandes mudanzas en la organización social constituida por los indígenas. Con la ayuda de algunos guaranís los colonizadores avanzaban e intentaban subyugar los nativos que encontraban delante de ellos. Los Guaycurús no aceptaron esa situación y
} 
integrados por tipos coloniales que, en la practica desde el punto de vista económico, quedaban excluidos de una situación cómoda de supervivencia. A parte de que estaban allí para aceptar cualquier modalidad de trabajo injusto $u$ honesto, pues muchos pasaban necesidades, a la vez que el hambre y la miseria en las villas lusas rayanas no fuera algo tan improbable. Así que la clasificación de los componentes de las expediciones tenían los pardos, Carijós, pardos "forros" (esto es, libertos) y mulatos. Porto Kok expone acerca de la "existencia de otro partícipe conocido como 'asistente', cuya condición era semejante al de un agregado, o sea, un morador que prestaba labor en una casa o propiedad de un pionero luso" ${ }^{66}$. Y pocos de estos hombres tenían matrimonio.

Del análisis de los datos acerca de la existencia o no de matrimonios de estos hombres fronterizos, es posible considerar que el número reducido de individuos casados es un indicativo fuerte de la inestabilidad, constante movimiento ${ }^{67}$ y de la pobreza de esos varones del interior rayano desconocido, sin bienes, propiedades o trabajo fijo. La condición existencial de las poblaciones errantes de la frontera demuestra, por ejemplo, que los "indios coloniales buscaban concebir nuevas identidades que apenas se alejasen de sus orígenes tribales, como también procurabanse diferenciar de los emergentes grupos sociales que eran frutos del mismo proceso colonial" ${ }^{68}$.

\section{Acerca de tratativas y marchas de guerra}

Por otra parte, las expediciones de castigo contra los naturales siguieron ocurriendo, pero con relativas victorias en eliminar las naciones indígenas. Eso exigió que las jurisdicciones iberocoloniales en la zona chaqueña hispano-lusa variasen la táctica de aniquilación de esos conjuntos nativos. "En 1733, el Oidor-General de la Villa del Buen Jesús del Cuyabá, el señor João Gomes Pereyra recomendó hacer acuerdo con el gentío Guaicurú que residía en las márgenes del río Paraguay" ${ }^{69}$. Es tolerable deliberar que el trato con los Mbayá-Guaicurúes beneficiaría la compraventa de caballos mbayá, justo lo que las minas lusas tanto necesitaban, y que podría ser cambiado miserablemente, entre otros bienes, por paños. Después, otra razón coexistiría en que los propios indios caballeros conseguirían entender las tendencias,

\footnotetext{
fueron siendo exprimidos por los colonizadores, de un lado los españoles, de otro los portugueses que a los pocos querían explorar las tierras donde hoy se encuentran los estados [brasileños] del Mato Grosso y Mato Grosso del Sur."

${ }^{66}$ Porto K., M. da G. 2009. “Os Kaiapó, os Mbayá-Guaicuru e os Payaguá”, p. 8.

${ }^{67}$ Silva, Giovani J. da. 2014. A reserva indígena Kadiwéu (1899-1984): memória, identidade e história, Dourados (Brasil), Editora da Universidade Federal da Grande Dourados, p. 53. Es posible manifestar que las poblaciones lusas seguían en inquebrantable movimiento territorial también debido a análisis acerca del siglo XVIII, como la hecha por esto historiador brasileño: "La continua resistencia que los Mbayá-Guaicurú ofrecieron a los portugueses, fue objeto de serias preocupaciones por parte de los colonizadores, los cuales intentaban siempre establecer una aproximación con los indios."

${ }^{68}$ Porto K., M. da G. 2009. “Os Kaiapó, os Mbayá-Guaicuru e os Payaguá”, p. 9.

69 Ídem, p. 10.
} 
incursiones i esfuerzos de los españoles en el área rayana. Otro hecho fue que los indios podrían se organizar para asaltar las urbes españolas y sojuzgar las márgenes del río Paraguay. Por fin, la última inspiración estaba en el tema que los oportunistas guaycurús alcanzarían a sofocar los remanecientes de la población Payaguá.

Esa "política fronteriza", si acaso puede llamarse así, de las autoridades lusas que mantenían el gobierno de la Villa del Cuyabá, no tuvieron la más mínima ética humana al hacer sus acuerdos deshonestos con los naturales Mbayá-Guaycurúes rayanos, los cuales accionaron sus guerreros con mucha ingenuidad, al aceptar las propuestas hechas por los portugueses interesados en el uso y manipulación de esta fuerza destructiva contra todas las etnias indígenas de la región fronteriza chaqueña central en América del Sur. Susnik pondera que el pacto Mbayá-Portugués circunstanció también una nueva evaluación económica. La práctica del trueque adquirió mayor importancia en sus asaltos realizados en la primera mitad del siglo 18 , los Mbayá-Caduveos trataban de apoderarse siempre de mayor número de ganado posible, pues la manada representaba un bien apreciable en la permuta con los amigos del norte. El instinto devastador Mbayá no fue olvidado. Sin embargo, en sus asaltos 'Ios 'Caduveos' destruían hasta árboles frutales y quemaban plantaciones cuando ellos mismos no podían aprovecharse de estos bienes subsistencial o comercialmente" ${ }^{\prime 70}$.

Los lusos alimentaron constantemente alguna esperanza de establecer relaciones seguras en sus intentos al celebrar sus acuerdos con los indígenas rayanos. La confiabilidad en estas negociaciones con los nativos quedaba casi perenemente plena, cuando creían que nada podría salir errado o fuera de su control. Pues en 1740, autoridades de la Real Villa del Cuyabá enviaron emisarios para hacer contrataciones y nuevas alianzas con los Guaycurúes, para, por medio de ellos, arruinaren los Payaguá. Una expedición partió entonces capitaneada por Antonio João de Medeiros, con doce canoas con 140 hombres con destino al territorio de los Mbayá-Guaicurú para regalarles "paños de colores, bateas, chitas, barretas, sombreros, cintas, colares, peines, facas, tejeras, machados, entre otros" ${ }^{\prime 11}$. En respuesta, los Guaicurú se ofrecieron cómo aliados en la guerra contra los Payaguá y contra los españoles. Pero al amanecer del día siguiente, contrariando el acuerdo, los Guaicurúes mataran 50 soldados lusos. Este episodio ilustra la frustración de los intentos lusos de intervención para dominar la zona rayana, más allá de la falibilidad de las fronteras entre amistades y traiciones por parte de los grupos indígenas.

En la primera mitad del siglo XVIII, en cuanto del lado portugués de una frontera central aún incierta, se erguían practicas criminales de acuerdos con etnias indígenas para asesinar otros grupos naturales. Del lado rayano español, las prácticas administrativas jesuíticas daban otros resultados. Así es que el establecimiento de reducciones implicó un acuerdo entre diferentes

\footnotetext{
${ }^{70}$ Susnik, B., 1970. Apuntes de Etnografía Paraguaya, p. 19.

${ }^{71}$ Porto K., M. da G. 2009. “Os Kaiapó, os Mbayá-Guaicuru e os Payaguá”, p. 10.
} 
agentes: por un lado, los grupos indígenas se comprometían a guardar la paz y a ofrecer ayuda táctica frente a los grupos no reducidos. Por otro lado, los vecinos de las villas se obligaban a abastecer con ganado y las demás provisiones necesarias a los grupos reducidos. Y finalmente, los jesuitas ansiaban la conversión de los nativos 'paganos', haciendo progresar la institución de reducciones capaces de autosustenerse a través de las actividades agrícolas: “Así nació San Javier (1743), la primera reducción de los indios 'moscoví"'72.

Algunas etnias de la gran nación Mbayá-Guaycurú, no obstante la faena violenta de las 'expediciones punitivas' en la zona colindante chaqueña, se mantenían vivas y actuantes instintivamente en resistir, demostrando gestos de agresiones al agente colonizador extranjero en sus territorios. En el área oriental por ejemplo, los Eyiguayégis-Mbayá-Guaycurúe también continuaron sus asaltos, negociando reiteradamente con los Payaguá, amenazando con desgracia a los poblados españoles y misionales. La principal utilidad de estos asaltos constituía aún el botín como valor económico, pero fue manifiesta ya una tendencia de expansión natural hacía las tierras subsistencialmente más fértiles del sur, pues su antiguo hábitat de cazadores, palmares y campos cultivados resultaba bastante empobrecido por causa de un intenso aprovechamiento. Su estructura socio-económica basada en la norma de "niyolola-vasalloscultivadores" se derrumbaba, por haber quedado gran parte de las comunidades Guaná en el hábitat chaqueño. En el año 1744, el gobernador Rafael de la Moneda organizó una de las primeras resistencias eficaces a los Mbayá. Esto no obstante, los “'Apacachodegodegís' bien pronto irrumpieron nuevamente en el territorio de los 'Monteses', 'Tarumá-Guaraníes', obteniendo un gran número de cautivos, en esta oportunidad, los jesuitas trasladaron algunos grupos 'Tarumáes' en las misiones"73.

Ya en la segunda parte del siglo XVIII se exteriorizan algunos episodios históricos llamativos acerca de las relaciones Guaycurúes ${ }^{74}$. En el año 1765, el grupo Apacachodegodegí con el cacique "Lorenzo" emprendió el camino hacia Asunción, donde debería concretarse un plan de ataque común, español-mbayá, a los nativos Lengua-Cochaboth. Los portugueses mientras tanto, enviaron un cautivo guaycurúe de la Villa del Cuyabá para sublevar a los Mbayá contra los españoles, circunstancia que les facilitaría la penetración lusa hacia el río Apa y la Villa de Curuguaty. El plan portugués fracasó, pero los Mbayá que se fueron a Asunción, experimentaron muestras de una gran hostilidad: les tiraron violentamente de las puertas de Asunción. El agotamiento por hambre, enfermedades y una epidemia de viruela quedaría en la

\footnotetext{
${ }^{72}$ Sol N., F., 2005. Los grupos mocovi en el siglo XVIII, p. 16.

${ }^{73}$ Susnik, B., 1970. Apuntes de Etnografía Paraguaya, p. 15.

${ }^{74}$ Carvalho de A., Ariane Aparecida. 2011. Condicionantes étnicos na criação das Missões de Chiquitos: alianças e conflitos na Chiquitania e no Pantanal. Disertación de maestría en historia, Porto Alegre, edita PUCRS - Pontífice Universidade Católica do Rio Grande do Sul, p. 47. Registra la historiadora que: "Luego, a partir de 1703, la aproximación entre distintos grupos indígenas (Payaguá, Mbayá-Guaicurú, Guarany y Chiquitos) culminó en una serie de conflictos, que perduró hasta la expulsión de los jesuitas, en 1767."
} 
memoria de los Eyiguayegi-Mbayá, que reiniciaron sus incursiones y asaltos: tanto los españoles como los portugueses tenían que implantar más puestos de defensa, como fue hecho por medio de los fortines de Olimpo, Alburquerque y Nueva Coímbra. La renovación del pacto de amistad Mbayá-Español en el año 1774 fue de poca duración. Unos diez años después, los Mbayá amenazaron nuevamente el pueblo de Concepción. "Finalmente firmaron los Mbayá el tratado de amistad con los portugueses en Villa Bella de la Santísima Trinidad (1791)"75.

El año de 1791 tiene importancia histórica, teniendo en cuenta que a partir de este período los lusos obtienen relativa recompensa en producir la hostilidad Mbayá-Guaycurúe contra los españoles. Posteriormente los Mbayá suscribieron el acuerdo de amistad con los portugueses en Villa Bella, el pueblo portugués más al este de América del Sur colonial lusa. "Este pacto determinó actitudes y comportamiento socio-político mbayá, imponiéndose hechos de represalia y de rivalidad contra los españoles ('Ecalais')" ${ }^{176}$.

La denominada "guerra justa" por los lusos, fue croncretada por intermedio de sus "expediciones punitivas" que se materializaron en los cuerpos trucidados de las naciones indígenas rayanas, siendo ejemplo de una absurda "acción civilizadora" del agente colonial europeo. Pues en la medida que el proceso de sometimiento de los naturales avanzaba por los territorios indígenas, en realidad, fuertes, presidios, haciendas y villas ya puntuaban la posesión de la región por las coronas ibéricas. En cuanto, poco a poco, se esfacelaban los movimientos de resistencia y las identidades guerreras amerindias. En la década de 1770, fueron fundados los presidios (disfrazados como fuertes), por ejemplo, del "Albuquerque y Nueva Coímbra, de verdad, muy eficaces en la 'guerra justa' contra los nativos para interrumpir la libre circulación de las etnias por la América del Sur meridional" ${ }^{\prime 77}$. Así que las marcas del proceso colonial se van haciendo presentes en la frontera histórica del mundo indígena suramericano.

El principio de justicia de la antigua Ley de Talión parece tener repercutido equivalentemente en América colonial. En algún momento, el efecto "ojo por ojo, diente por diente", sí que parece tener sido aplicado por la nación Mbayá-Guaycurú a los lusos y sus sangrientas "guerras justas". En la investigación detenida de las actas del Senado de la Cámara del Cuyabá, se constata un registro que ha despertado interés histórico, pues en el día 6 de enero de 1778, fue cuando el presidio de Nueva Coímbra recibe visitantes nativos:

"Amaneció el día que se celebraría los Santos Reyes Magos y por las ocho horas llegó una 'maquina' [multitud] de 'Aicurús' [Guaycurúes] a titulo de hacer visita. Sabiendo fabricar mejor su engaño llegaron hombres y mujeres gritando como se viesen en paz. El gentío nativo tenía dos 'lenguas' [indios traductores], un del castellano y otro que hablaba el portugués. Y los soldados lusos con deseo de miraren los naturales y se comunicaren con

\footnotetext{
${ }^{75}$ Susnik, B., 1970. Apuntes de Etnografía Paraguaya, p. 17.

${ }^{76}$ Susnik, B., 1970. Apuntes de Etnografía Paraguaya, p. 18.

${ }^{77}$ Porto K., M. da G. 2009. “Os Kaiapó, os Mbayá-Guaicuru e os Payaguá", p. 13.
} 
ellos resultaron por olvidarse de las 'habituales traiciones' de los 'bugres' [indígenas]. Los soldados, sin temeridad alguna pasaron a se mesclar y charlar con los indios en tal forma que todos parecían sin diferencia de naciones. Y repentinamente descargaron aquellos 'pésimos e infames traidores' toda su furiosa ira en contra nuestros soldados que quedaban desarmados y en breves instantes mataron 54 personas, entre ellos el comandante, el cirujano del presidio, soldados de la Compañía de Dragones, un negro esclavo, un pardo, oficiales, colonos, todos degollados. Los 'Aicurús' robaron ropas y caballos huyendo a toda prisa" $^{78}$.

Situaciones como esta descripta en las actas del Senado de la Cámara del Cuyabá demuestra una sencilla característica del hombre guaycurúe en su imprevisibilidad. Pero no solo un hecho que sirvió para denegrir la imagen histórica de la nación mbayá. Ellos tenían su forma de vivir; no estaban contentos para nada con la presencia crecente de los pioneros colonos ibéricos en su tierra ancestral. Creemos que a las naciones indígenas pertenecía el justo derecho de resistir $^{79}$ al proceso colonial, o sea, de luchar como lo sabían ante las barbaries cometidas por las autoridades ibéricas. Es posible que, en la andadura de la crueldad sembrada por los lusos, intuitivamente los Guaycurúes sintieran que era una querella de vida o muerte.

La metodología de estudio de los grupos indígenas coloniales basado en la identificación de troncos lingüísticos presentó buena posibilidad para una investigación pues quedó posible realizar algunas lecturas interpretativas de naturaleza histórica y antropológica rumbo a la identificación de la gran familia étnica Mbayá-Guaycurúe. En el inicio del siglo XVIII, el Chaco se había constituido en un espacio multiétnico de gran movilidad interna. Durante los siglos previos sucesivas oleadas migratorias habían contribuido a conformar este espacio, una de estas ondas, "proveniente del área pampeano patagónica, habría conllevado el arribo de algunos grupo al oriente chaqueño. Posteriormente, ellos conformarían los pueblos de la familia lingüística guaycurú, dentro de la cual encontramos a los mocovi" ${ }^{80}$.

\section{Conclusiones}

A título de desenlace aceptamos la importancia de los ríos centrales del continente suramericano donde vivía una muchedumbre de tribus indígenas con la presencia de la nación

\footnotetext{
${ }^{78}$ Takamoto S., Y. 2007. Annaes do Sennado da Camara do Cuyabá. Año de 1778, pp. 53 y 53 (verso).

${ }^{79}$ Lopes de C., Francismar Alex. 2006. "Etnogênese mbayá-guaykuru: notas sobre emergência identitária, expansão territorial e resistência de um grupo étnico no vale do rio paraguai (c. 1650-1800)", en Fénix Revista de Historia e Estudos Culturais, volumen 3, numero 4, Uberlândia (Brasil), p. 17. Este historiador brasileño refleja acerca del resistir guaycurúe que: "Al final del siglo XVIII, quedaba definitivamente claro para los Mbayá la imposición de una territorialización intolerable por parte de los dos grupos colonizadores. [...] Los conflictos se acerrarán por todas las partes, como forma de resistencia a la territorialización forzada. Desde 1788, os 'Apacachodegodegis' [Guaycurú] emprendían resistencia contra la invasión de sus territorios ecológicos al sur del río Apa por los hacenderos españoles, ávidos por los terrenos de excelente cualidad allí existentes."

${ }^{80}$ Sol N., F., 2005. Los grupos mocovi en el siglo XVIII, p. 51.
} 
Mbayá-Guaycurúe, entendida como señora de dominio de una extensión territorial formidable con fundamento en los ríos rayanos. La región de caza mezclada con los hábitos nómadas de los guaycurús presentará la característica esencial de movilidad y desplazamiento constante de esta nación nativa.

Una de las culminaciones posibles también es identificar la violencia de la acción colonizadora materializada por las expediciones de exploración enviadas por las autoridades ibéricas que destrozará muchas naciones de naturales en el corazón de Suramérica. La verdadera guerra de eliminación suscitada por los agentes coloniales produjo también alianzas entre españoles y Guaranís en contra indígenas Payaguá y Mbayá-Guaycurúe.

Pero hubo alianzas Guaycurú-Payaguá que después se cambiaran como naciones enemigas que resolvieron partir para la guerra de fratricidio y aniquilamiento reciproco. Todo esto, en algunas oportunidades, bajo la incitación lusa. Ahora, es verdad que también los portugueses patrocinaran las expediciones conocidas como "punitivas" contra numerosas naciones de naturales, incluso no para castigar, pero para devastar los Mbayá. De Lisboa ha venido la determinación de una nueva normativa: el "derecho" de exterminar las tribus que no fuesen posibles de colonizar, o sea, no domeñables. En esto, hay que considerar igualmente que, presidios y fuertes fueron levantados como parte de una metodología colonial para concretar la frontera hispano-lusa en el siglo XVIII, pero en realidad esta fue una de las maniobras para romper la reconocida libre circulación de las naciones indígenas y exterminar las poblaciones nativas.

En cuanto a algunas de las tradiciones y prácticas culturales de los Mbayá-Guaycurúe, interesante resaltar que ellos tenían algún respeto por los meses de recolecta de frutos silvestres en los bosques y florestas, esto es, no peleaban en los días en que preparaban los aprovisionamientos. Así que los rituales de primavera eran tiempos de relativa paz, época del año para charlas visando pactos y alianzas. Necesario también enmarcar la presencia del caballo español venido de Europa incorporado por los nativos Mbayá, muchas veces resultante de hurtos, pero establecido entonces como instrumento guerrero estratégico en las batallas y tácticas de guerrilla para luchar contra las tropas del agente colonial hispano-portugués. Después, también comercializado ilegalmente en la frontera para los lusos.

Otro elemento destacable fue la composición de las poblaciones guaycurús, que podrían ser mantenidas además por intermedio de detención de niños y mujeres oriundas de otras naciones indígenas. Las cuales, se podrían tornar esclavas en trabajos domésticos para las familias Mbayá. Queda claro una percepción de que los Guaycurúes sabían hacer transacciones comerciales rudimentales en la frontera lusa intercambiando productos, incluso seres humanos con contrabandistas portugueses.

Posteriormente tenemos que destacar la resistencia de los naturales intentando frenar el empuje colonial cuyo liderazgo estuvo por buenos años en las manos de parcialidades Mbayá, 
donde la competencia y habilidad Guaycurúe en combatir robusteció un protagonismo de supremacía Mbayá reforzando la tenacidad indígena frente a las agresiones de las milicias pioneras hispano-lusas. No obstante, la baja bélica Guaycurúe por enfermedades y derrotas a los indios Chiquitanos, entonces más preparados para defender sus respectivos territorios, bajo la administración ignaciana.

Por fin, apuntamos la indefinición de la frontera central luso-española aún al final del siglo XVII y en la llegada del siglo XVIII, que siguió por gran parte de este siglo, favoreciendo una expresiva porosidad de las bordas coloniales donde las naciones indias tenían sus tierras ancestrales. Esta permeabilidad fronteriza benefició la heroica resistencia nativa con activa participación Guaycurúe, que resultaron por sucumbir delante del auténtico holocausto histórico indígena hecho por colonos españoles y lusos.

\section{Bibliografía}

Amado, Janaína; Caselli Anzai, Leny. 2006. Anais de Vila Bela 1734 - 1789, Cuiabá, Editora Carlini \& Caniato.

Assis Andrade, Austin de; Weber, Astor. 2013. "A política luso-brasileira em relação aos EyiguayeguiMbayá-Guaicuru na Capitania de Mato Grosso", en Anais do VIII Encontro de Produção Científica $e$ Tecnológica, Universidade Estadual do Paraná, Campo Mourão (Brasil).

Calvo, Luís Maria; Benzi, Marina. (Sin fecha). "Florián Paucke, un austríaco en tierras mocovíes", en Museo Etnográfico y Colonial Juan de Garay, Departamento de Estudios Etnográficos y Coloniales, Argentina, Provincia de Santa Fe.

Carvalho de Arruda, Ariane Aparecida. 2011. Condicionantes étnicos na criação das Missões de Chiquitos: alianças e conflitos na Chiquitania e no Pantanal. Disertación de maestría en historia, Porto Alegre, edita PUCRS - Pontífice Universidade Católica do Rio Grande do Sul.

Galera Gomes, Andrés. 1990. Descripción General del Paraguay de Félix de Azara, edición, introducción y notas de Andrés Galera Gómez, Madrid, Alianza Editorial.

Garavaglia, J. Carlos; Marchena F., Juan. 2005. Historia de América Latina - De los orígenes a 1805, Volumen II, Barcelona, Crítica S.L.

Limpias Ortiz, Victor Hugo. 2007. "Misión de Moxos", en APUNTES: Revista de Estudios sobre Patrimonio Cultural, vol. 20, número 1, Bogotá, Pontificia Universidad Javeriana.

Lopes de Carvalho, Francismar Alex. 2006. “Etnogênese mbayá-guaykuru: notas sobre emergência identitária, expansão territorial e resistência de um grupo étnico no vale do rio paraguai (c. 16501800)", en Fénix Revista de Historia e Estudos Culturais, volumen 3, numero 4, Uberlândia (Brasil).

Porto Kok, Maria da Glória. 2009. “Os Kaiapó, os Mbayá-Guaicuru e os Payaguá nos desertos, ainda indecisos, pela linha imaginária (Século XVIII)", en Anales del VIII Reunión de Antropología del Mercusur 'Diversidad y Poder en América Latina', Buenos Aires, Mercosur.

Rodrigues F., Alexandre. 2008. Viagem Filosófica (pelas Capitanias do Grão-Pará, Rio Negro, Mato Grosso e Cuiabá), Manaus, Editora Vader.

Silva, Giovani José da. 2014. A reserva indígena Kadiwéu (1899-1984): memória, identidade e história, Dourados (Brasil), Editora da Universidade Federal da Grande Dourados.

Sol Nesis, Florencia. 2005. Los grupos mocoví en el siglo XVIII, Buenos Aires, Sociedad Argentina de Antropología.

Susnik, Branislava. 1970. Apuntes de Etnografía Paraguaya, Asunción, Manuales del Museo Etnográfico Andrés Barbero. 
Takamoto S., Yumiko. 2007. Annaes do Sennado da Camara do Cuyabá (1719 - 1830), (traducción y organización de Yumiko Takamoto Suzuki), Cuiabá, Editora Entrelinhas.

Turner, Frederick J. 1991. "El significado de la frontera en la Historia americana", en Estudios (Nuevos y Viejos) sobre la Frontera, Solano, Francisco; Bernabéu, Salvador (Coordinadores), Madrid, Centro de Estudios Históricos. 